\title{
Variation of Sym Plasmid and Symbiotic Effectiveness in Isolates of Rhizobium fredii
}

\author{
CHEN WENLI LI FUDI ZHOU JUNCHU \\ Department of Microbiology, Huazhong Agricultural University, Wuhan, 430070 \\ (Received January 13, 1995: Revised March 31, 1995)
}

ABSTRACT

The genetic diversity of symbiotic plasmids (pSyms) and symbiotic effectiveness was investigated in 11 isolates from one field population of Rhizobium fredii that had previously been characterized for plasmid content and serogroup polymorphisms. Two cloned DNA fragments from plasmid pSA30 and pIJ1216 were used as nif HDK and nod DABC probes respectively to identify pSym variation. Although only a single plasmid hybridized to both nif and nod probes in each strain tested. pSym size variation was great ranging from 247 to $381 \mathrm{MDa}$. In addition to $\mathrm{pSym}$, all of the $R$. fredii strains studied carried $1 \sim 5$ other plasmids, of which one was approximately $500 \mathrm{MDa}$ cryptic megaplasmid. The strains with different size of pSym significantly varied in their symbiotic effectiveness determined by their chlorophyll content, total $\mathrm{N}$. dry weight of the plant and nitrogenase activity.

Key words Rhizobium fredii, sym plasmid, symbiotic effectiveness, variation

\section{Introduction}

Rhizobium strains are gram-negative soil bacteria which induce symbiotic nodules on the roots of leguminous hosts for atmospheric nitrogen fixation. Plasmids in most Rhizobium species carry genes controlling symbiotic functions, which are clustered on a single large plasmid termed "pSym" (Banfalvi et al., 1981: Barbour et al., 1985; Krol et al. . 1982; Rosenberg et al. . 1981). Two or more plasmids that carry genes controlling symbiotic functions have been found in certain strains of $R$. leguminosarum biovar trifolii (Hynes et al., 1990), of $R$. etli (Brom et al., 1992) and of $R$. meliloti (Hynes, et al., 1986). Besides pSym (s), Rhizobium strains usually contain additional plasmids. The number of plasmids ranges from two to four or five, and may be as many as ten (Thurman, et al., 1985). Because there is high variability, plasmid profile analysis has proven to be a useful tool for differentiating Rhizobium strains and determining their diversity (Glynn, et al., 1985; Harrison, et al., 1988; Hartmann, et al., 1991: Young et al. , 1988).

Differences in pSym within $R$. leguminosarum have been noted (Hombrecher et al. , 1981; Young et al., 1988). R. leguminosarum biovar trifolii and phaseoli, and $R$. fredii contain large plasmids varying in size from 100 to $300 \mathrm{MDa}$ that carry genes involved in nodulation (nod) and symbiotic nitrogen fixation ( $f i x$ ), as well as the nitrogenase structural genes (nifHDK) (Beynon, et al., 1980; Barbour, et al., 1985; Harri- 
son, et al., 1988).

In our previous study, genetic diversity have been demonstrated in Rhizobium fredii population from the soil of Honghu County, Hubei Province by plasmid content and serogroup polymorphisms (Chen et al., 1994). This study investigated pSym variation in a number of $R$. fredii strains from that population and assessed their symbiotic effectiveness.

\section{Materials and methods}

2. 1 Bacterial strains and plasmids: Bacterial strains and plasmids utilized in this study are listed in Table 1. Except USDA 205, all of the $R$. fredii strains tested were isolated from the soil of Honghu County, Hubei Province (Chen et al., 1994).

Table 1 Bacterial strains and plasmids.

\begin{tabular}{|c|c|c|c|}
\hline \multicolumn{2}{|c|}{ Strain or plasmid } & Relevant Characteristics & References \\
\hline \multirow[t]{13}{*}{ R. fredii } & $\therefore$ & & \\
\hline & HA $1-1-4$ & $\mathrm{Nod}^{+} \mathrm{Fix}^{+}$, wild type & Chen W L, Li F D, Zhou J C, et al. (1994) \\
\hline & HA 12-1-12 & $\mathrm{Nod}^{+} \mathrm{Fix}^{+}$, wild type & Chen W L, Li F D, Zhou J C, et al. (1994) \\
\hline & HA $12-1-11$ & $\operatorname{Nod}^{+}$Fix $^{+}$, wild type & Chen W L, Li F D, Zhou J C, et al. (1994) \\
\hline & HA 8-1-4 & $\mathrm{Nod}^{+} \mathrm{Fix}^{+}$, wild type & Chen W L, Li F D, Zhou J C, et al. (1994) \\
\hline & HA 9-1-9 & $\mathrm{Nod}^{+} \mathrm{Fix}^{+}$, wild type & Chen W L. Li F D, Zhou J C, et al. (1994) \\
\hline & HA 13-2-6 & $\mathrm{Nod}^{+} \mathrm{Fix}{ }^{+}$, wild type & Chen W L, Li F D, Zhou J C, et al. (1994) \\
\hline & HA 8-1-8 & $\mathrm{Nod}^{+} \mathrm{Fix}^{+}$, wild type & Chen W L, Li F D, Zhou J C, et al. (1994) \\
\hline & HA $7-2-2$ & Nod $^{+}$Fix $^{+}$. wild type & Chen W L, Li F D, Zhou J C, et al. (1994) \\
\hline & HA $13-2-1$ & - Nod $^{+}$Fix ${ }^{+}$. wild type & Chen W L, Li F D, Zhou J C, et al. (1994) \\
\hline & HA $6-1-20$ & $\mathrm{Nod}^{+} \mathrm{Fix}^{+}$, wild type & Chen W L, Li F D, Zhou J C, et al. (1994) \\
\hline & HA 9-1-10 & $\mathrm{Nod}^{+} \mathrm{Fix}^{+}$, wild type & Chen W L, Li F D, Zhou J C, et al. (1994) \\
\hline & USDA205 & $\mathrm{Nod}^{+} \mathrm{Fix}^{+}$, wild type & Keyser HH, Bohlool BB, Hu TS, et al. (1982) \\
\hline \multicolumn{4}{|l|}{ Plasmid } \\
\hline & pSA30 & \multicolumn{2}{|c|}{$\begin{array}{ll}\text { 6. } 2 \mathrm{Kbp} \text { EcoRI restriction fragment } & \text { Cannon F C, Riedel G E and } \\
\text { carrying the nifHDK of } K \text {. pneumoniae } & \text { Ausubel F M (1979) } \\
\text { cloned into pACYC184 } & \end{array}$} \\
\hline & pIJ1216 & $\begin{array}{l}\text { 6. } 6 \mathrm{Kbp} \text { EcoRI restriction fragment } \\
\text { carrying the nodDABC of } R \text {. legumi- } \\
\text { nosarum cloned into } \mathrm{pKT} 230\end{array}$ & $\begin{array}{l}\text { Downie J A, Knight C D, Jo- } \\
\text { hnston A W B, et al. (1985) }\end{array}$ \\
\hline
\end{tabular}

2. 2 Leguminous plant: Soybean (Glycine max) cultivar Aijiaozao was used in this 
study, which was kindly provided by Institute of Oil Crops, Chinese Academy of Agricultural Sciences. It was the cultivar planted in Honghu County, where the $R$. fredii strains tested were isolated.

2. 3 Isolation of plasmid DNA and plasmid visualization: $R$. fredii strains were grown in PA media (Peptone $4 \mathrm{~g} \cdot \mathrm{L}^{-1}, \mathrm{MgSO}_{4} \cdot 7 \mathrm{H}_{2} \mathrm{O} 0.5 \mathrm{~g} \cdot \mathrm{L}^{-1}, \mathrm{pH} \mathrm{6.8 \sim 7.0)} \mathrm{overnight}$ (to a concentration of approximately $10^{7}$ cells $\mathrm{ml}^{-1}$ ) following inoculation with actively growing culture. Cell culture $(1 \mathrm{ml})$ was centrifuged and to the pellet was added $50 \mu \mathrm{l}$ of lysis mix ( $1 \mathrm{mg}$ lysozyme $\mathrm{ml}^{-1}, 1$ unit RNAase $\mathrm{ml}^{-1}$ in $25 \% \mathrm{~W} / \mathrm{V}$ sucrose and $0.025 \mathrm{~mol}$ - $\left.\mathrm{L}^{-1} \mathrm{Tris} / \mathrm{HCl}\right)$. This mixture was immediately transferred to the sample wells of a $0.65 \%(\mathrm{~W} / \mathrm{V})$ agarose gel, a single wide well containing $0.4 \%(\mathrm{~W} / \mathrm{V})$ agarose and $1 \%$ (W/V) SDS was incorporated behind these wells. A horizontal gel kit was used to run gels at $100 \mathrm{~V}$ for $5 \mathrm{~h}$ in Tris/borate buffer ( $\mathrm{pH} 8.3$ ). Gels were stained in a solution of $1 \mu \mathrm{g}$ ethidium bromide $\mathrm{ml}^{-1}$ for $40 \mathrm{~min}$.

Plasmid size was determined by calibration against the relative mobilities of four plasmids in USDA205 whose sizes were known as 7, 120,230,450MDa respectively (Broughton W J, Heycke N, Meyer H Z A, et al., 1984).

2. 4 Southern blotting and hybridization: Plasmid DNA were Southern blotted from the gel to a Gene Screen (Du pont, product of NEN) following the manufacturer' s instruction. Two DNA probes were used in this study, 6. $2 \mathrm{Kbp}$ EcoRI restriction fragment from pSA30 and $6.6 \mathrm{Kbp}$ EcoRI restriction fragment from pIJ1216. Labelling of probes, hybridization to the membrane, and detection of hybrid DNA were done with the Nonradioactive DNA Labelling and Detection Kit from Boehringer Mannheim, according to the instructions provided with the kit.

2. 5 Plant inoculation tests: Plants were grown in the assembly pot similar to Leonard jar designed by this laboratory. Sand was filled in a plastic cup with a small hole at the bottom through which a wick was anchored. The cup was loaded onto a glass bottle containing Fahraeus nitrogen-free solution (Fahraeus, 1957). The whole device was sterilized at $121^{\circ} \mathrm{C}$ for 120 min. Seeds of soybean (Glycine max) cultivar Aijiaozao were preimmersed in $95 \%$ ethanol for 5 min, surface -sterilized with $0.1 \% \mathrm{HgCl}_{2}$ for 5 min and rinsed with sterile water for 10 times. Sterilized seeds were germinated on water agar plate for 2 days in darkness at $28^{\circ} \mathrm{C}$. The resulting seedlings were planted singly in chamber sand pot and inoculated with $1 \mathrm{ml}$ of late log-phase culture $\left(10^{8}\right.$ cells $\left.\mathrm{ml}^{-1}\right)$ of each strain grown in yeast extract mannitol (YEM) broth culture when the cotyledons opened. There were 8 replicates per treatment and the experiment was arranged in a completely randomized design. Uninoculated plants were served as controls. Throughout the duration of the plant test, no nodules were found in the uninoculated control plants, showing the absence of rhizobial contamination. Plants were grown in a green house under natural light and harvested at 40 days after inoculation.

Effectiveness of rhizobial strains was determined by chlorophyll content, nitrogenase activity, total $\mathrm{N}$ and dry weight of the soybean shoots.

2. 6 Chlorophyll measurement: Chlorophyll content determination was done by some modification of the method described by Mirza N A, Bohlool B B and Somasegaran P (1990). At harvest, using a standard single-hole punch 12 leaf discs (6. $35 \mathrm{~mm}$ dia) were cut from leaflets of each plant taken at random but excluding the youngest and the oldest trifoliates leaves. After weighed, leaf discs were transferred immediately to 
screw-capped glass vials containing $5 \mathrm{ml}$ of $95 \%$ ehanol. Chlorophyll was extracted by keeping the vials at $85^{\circ} \mathrm{C}$ for $30 \mathrm{~min}$. Then $95 \%$ ethanol was added to the $10 \mathrm{ml}$ mark of vials. Chlorophyll $(\mathrm{a}+\mathrm{b})$ concentration was determined spectrophotometrically at $645 \mathrm{~nm}$ and $663 \mathrm{~nm}$.

2. 7 Acetylene reduction assay: Nitrogenase activity was measured by acetylene reduction performed on the intact root system including nodules. Roots were separated from shoots at the cotyledon scars and placed in a $20 \mathrm{ml}$ sealed vial. The reaction was started with an air gas phase containing $2 \%(\mathrm{~V} / \mathrm{V})$ acetylene. After incubating for $1 \mathrm{~h}$ samples were injected into a Hitach 163 gas chromatography with a Porapak N 80 100 column and nitrogen carrier gas at $90^{\circ} \mathrm{C}$. Nitrogenase activity was expressed as micromoles of ethylene produced per milligram of nodule fresh weight per hour.

2. 8 Kjeldahl determination of plant total $\mathrm{N}$ : The plant tops were oven dried at $65^{\circ} \mathrm{C}$ for $48 \mathrm{~h}$ and dry weight recorded. $0.2 \mathrm{~g}$ of the finely ground plant material was subjected to $\mathrm{Kjeldahl}$ digestion for $1 \mathrm{~h}$ at $440^{\circ} \mathrm{C}$. Total $\mathrm{N}$ was then determined by a semi-microKjeldahl procedure.

2.9 Statistical analysis: Each experiment was analysed separately by analysis of variance for a completely-randomized design. The Duncan's Multiple Range Test was used to compare the means of strain treatments.

\section{Results}

3. 1 Plasmid profiles and plasmid characterization

The isolates of $R$. fredir examined exhibited much variation in plasmid profile (In Cover Page 3 Fig. 1a, 2a). Two to six plasmids were reproducibly detected in each strain. By calibration against the relative mobilities of four plasmids in USDA205 with known sizes of $70120230450 \mathrm{MDa}$ respectively (Broughton W J, Heycke N, Meyer H $\mathrm{Z} \mathrm{A}$, et al. , 1984), the plasmid sizes of the tested strains ranged from 12 to $530 \mathrm{MDa}$ (Table 2). A characteristic large plasmid (about $500 \mathrm{MDa}$ ) was present in all the strains. This diversity of plasmid profiles demonstrated the existence of a great heterogeneity of plasmid pools within $R$. fredii strains examined.

3. 2 Location of symbiotic genes on plasmids

Eckhardt gels used for visualization of plasmids were transferred to a Gene Screen, then hybridized to nif $\mathrm{HDK}$ and nod $\mathrm{DABC}$ probes respectively (In Cover Page 3 Fig. $1 b, 2 b)$. In each strain, only one plasmid band hybridized to the nif probe. This plasmid band also hybridized to the nod probe. The sizes of the hybridized plasmids (pSym) ranged from 247 to $381 \mathrm{MDa}$ (Table 2). The other megaplasmids harbored by the $R$. fredii strains studied did not hybridize to the nif or nod probe.

3. 3 Effectiveness of rhizobial strains

All of the $R$. fredii strains examined effectively nodulated soybean cultivar Aijiaozao with efficient nitrogen fixation (Table 3). HA12-1-12 was apparently the most effective strain as judged by chlorophyll content, total $N$, nitrogenase activity and plant dry weight. Significant difference between $R$. fredii strains tested was found in chlorophyll content and other parameters. The effectiveness of strains with different plasmid profile varied. 
Table 2 The number and approximate sizes of the plasmids of each strain tested.

\begin{tabular}{cll}
\hline Strain & No. of plasmids & Sizes of plasmids (MDa)* \\
\hline HA1-1-4 & 2 & $490, \underline{318}$ \\
\hline HA12-1-12 & 3 & $490, \underline{275}, 201$ \\
\hline HA12-1-11 & 3 & $497, \underline{259,156}$ \\
\hline HA $8-1-4$ & 3 & $478, \underline{326}, 112$ \\
\hline HA $9-1-9$ & 4 & $472, \underline{247}, 186,70$ \\
\hline HA13-2-6 & 4 & $490, \underline{326}, 113,59$ \\
\hline HA $8-1-8$ & 5 & $523, \underline{354}, 275,203,56$ \\
\hline HA $7-2-2$ & 5 & $530, \underline{381}, 148,94,55$ \\
\hline HA13-2-1 & 5 & $510, \underline{282}, 201,124,40$ \\
\hline HA $6-1-20$ & 6 & $510, \underline{296}, 203,70,32,12$ \\
\hline HA 9-1-10 & 6 & $454, \underline{314}, 250,164,64,40$ \\
\hline * The numbers underlined correspond to sizes of plasmids showing hybridization to nifHDK and nodDABC probes in \\
experiments such as that shown on Fig. 1, 2
\end{tabular}

Table 3 Effectiveness of $R$. fredii strains on soybean.

\begin{tabular}{|c|c|c|c|c|}
\hline Strain & $\begin{array}{l}\text { Chlorophyll }(a+b) \\
\text { content }\left(\mathbf{m g} \cdot \mathbf{g}^{-1}\right)\end{array}$ & $\begin{array}{c}\text { Plant } \\
\text { dry weight }(g)\end{array}$ & $\begin{array}{c}\text { Toal N } \\
\text { (mg. plant } \\
\end{array}$ & $\begin{array}{c}\text { Amount of acetylene } \\
\text { reduced } \\
\left(\mu \mathrm{molC}_{2} \mathrm{H}_{4} \cdot \mathrm{g}^{-1} \mathrm{hr}^{-1}\right)\end{array}$ \\
\hline CK & $0.307 \mathrm{f} *$ & $0.265 \mathrm{~d}$ & $2.833 \mathrm{~h}$ & 0 \\
\hline USDA205 & 1. $142 \mathrm{e}$ & $0.461 \mathrm{c}$ & $9.128 \mathrm{~g}$ & $5.136 \mathrm{~g}$ \\
\hline HA12-1-11 & $1.627 \mathrm{~d}$ & $0.536 \mathrm{bc}$ & $8.409 \mathrm{~g}$ & $6.565 f$ \\
\hline HA13-2-1 & $1.631 \mathrm{~d}$ & $0.553 \mathrm{bc}$ & $11.778 \mathrm{f}$ & $6.878 f$ \\
\hline HA $1-1-4$ & $1.713 \mathrm{~cd}$ & $0.560 \mathrm{~b}$ & $12.905 f$ & $7.035 \mathrm{f}$ \\
\hline HA $8-1-8$ & $1.822 c$ & $0.578 b$ & $13.320 \mathrm{f}$ & $9.671 \mathrm{e}$ \\
\hline HA $13-2-6$ & $2.173 b$ & $0.643 \mathrm{ab}$ & $17.756 \mathrm{e}$ & $12.265 \mathrm{~d}$ \\
\hline HA $7-2-2$ & $2.178 \mathrm{~b}$ & $0.661 \mathrm{ab}$ & 16. $208 \mathrm{de}$ & 13. $202 \mathrm{~cd}$ \\
\hline HA $6-1-20$ & 2. $228 \mathrm{ab}$ & $0.675 \mathrm{ab}$ & $18.894 \mathrm{~cd}$ & $13.465 c$ \\
\hline HA 8-1-4 & $2.238 \mathrm{ab}$ & $0.688 \mathrm{a}$ & $20.739 \mathrm{bc}$ & $13.975 c$ \\
\hline HA 9-1-10 & 2. $324 \mathrm{ab}$ & $0.706 \mathrm{a}$ & $21.501 \mathrm{~b}$ & $15.435 \mathrm{~b}$ \\
\hline HA 9-1-9 & $2.340 \mathrm{ab}$ & $0.720 \mathrm{a}$ & $23.179 \mathrm{~b}$ & $17.146 \mathrm{a}$ \\
\hline HA 12-1-12 & $2.372 \mathrm{a}$ & $0.809 a$ & $28.705 a$ & $17.220 \mathrm{a}$ \\
\hline
\end{tabular}

* Values are the means of eight replications

Means having the same letters within a column were not significantly different by Duncan's Multiple Range Test at $1 \%$ probablility

- 40 . 


\section{Discussion}

This investigation reveals genetic diversity among $11 R$. fredii strains with different plasmid profile from Honghu County. Hubei Province. The results of location of symbiotic genes indicated that a great variation in size of pSym existed in $R$. fredii strains examined. These results corroborate the report of pSym size differences by Hombrecher et al. (1981), Krol et al. (1982) in R. leguminosarum bv. viceae, and by Harrison et al. (1988) in R. leguminosarum bv. trifolii. A number of explanations can be put forward to account for this diversity. The instability and tendency of pSym to be deleted under particular conditions have been recognized by Zurkowski. (1982); presumably conditions within natural environments may occasionally favor such deletions, thereby generating size differences in indigenous pSyms. Ronson et al. (1983) showed the readiness of pSym to recombine with cryptic plasmids which could result in a pSym carrying a large proportion of non-symbiotic'DNA. Moreover, recombination between different pSyms has been reported (Christensen et ral., 1983).

In all the strains examined, a single plasmid ranging from 247 to $381 \mathrm{MDa}$ was shown to contain the symbiotic determinants. A characteristic plasmid, about 500MDa, was present in each strain. Unlike R. meliloti (Banfalvi et al. , 1981; Rosenberg et al. . 1981), this megaplasmid does not seem to contain nifHDK or nod DABC genes. However, on the basis of its presence in all strains, this megaplasmid may specifically encode some unknown genetic information relevant to either the symbiosis or the survival of the bacteria in the soil, and it merits further study.

The significant difference between $R$. fredii strains studied was observed in their effectiveness. Contrary to the work of Thurman et al. (1985), we did not find a negative correlation beween the total number of plasmids or pSyms and dry weight of plants. It showed that the effectiveness of stains with different size of pSym varied.

\section{ACKNOWLEDGEMENT}

This work is part of the joint EC-project no. TS3-CT92-0127 and was supported in part by the National Natural Science Foundation of China (NSFC).

\section{REFERENCES}

Banfalvi Z. Sakanyan V. Konez C, et al., 1981. Location of nodulation and nitrogen fixation genes on a high molecular weight plasmid of Rhizobium meliloti. Mol. Gen. Genet., 184: 318 325

Barbour W M, J N Mathis, G H Elkan. 1985. Evidence for plasmid-and chromosome-borne multiple nif genes in Rhizobium fredii. Appl. Environ. Microbiol., 50: 41 44

Beynon J L, J E Beringer, A W B Johnston, 1980. Plasmids and host range in Rhizobium leguminosarum and Rhizobium phaseoli. J. Gen. Microbiol., 120: $421 \sim 429$

Brom S, Garcia de los Santos A, T Stepkowsky, et al., 1992. Different plasmids of Rhizobium leguminosarum bv. phaseoli are required for optimal symbiotic performance. J. Bacteriol., 174: 5183 5189

Broughton W J, N Heycke, H Z A Meyer et al., 1984. Plasmid-linked nif and nod genes in fast growing rhizobia that nodule Glycine max, Psophocarpus tetragonolobus, and Vigna unguiculata. Proc. 
Natl. Acad.Sci. USA., 81: 3093 3097

Cannon F C, G E Riedel, F M Ausubel, 1979. Overlapping sequences of Klebsiella pneumonia nif DNA cloned and characterized. Mol. Gen. Genet., 174: 59 66

Chen W L, F D Li, J C Zhou, et al., 1994. Diversity of Rhizobium fredii strains in the soil of Honghu County, Hubei Province. J. Huazhong Agricultural University, 13:581 587 (in Chinese)

Christensen A H, K R Schubert, 1983. Identification of a Rhizobium trifolii plasmid coding for nitrogen fixation and nodulation genes and its interaction with pJB5JI, a Rhizobium leguminosarum plasmid. J. Bacteriol., 156: 592 599

Downie J A, C D Knight. A W B Johnston, et al., 1985. Identification of genes and gene products involved in the nodulation of peas by Rhizobium leguminosarum. Mol. Gen. Genet. 198: 255 262

Fahraeus G, 1957. The infection of clover root hairs by nodule bacteria studied by a simple glass slide technoque. J. Gen. Microbiol., 16: 374 381

Glynn P, P Higgins, A Squartini, et al., 1985. Stain identification in Rhizobium trifoliiusing DINA restriction analysis, plasmid DNA profiles and intrinsic antibiotic resistance. FEMS Microbiol. Lett., 30: $177 \sim 182$

Harrison S P, D G Jones, P H D Schunmann, et al., 1988. Variation in Rhizobium leguminosarum biovar trifolii Sym plasmids and the association with effectiveness of nitrogen fixation. J. Gen. Microbiol., 134: 2721 2730

Hartmann A. N Amarger, 1991. Genotypic diversity of an indigenous Rhizobium meliloti fiéld population assessed by plasmid profiles. DNA fingerprinting, and insertion sequence typing. Can. J. Microbiol., 37: $600 \sim 608$

Hombrecher G. N J Brewin, A W B Johnston, 1981. Linkage of genes for nitrogenase and nodulation ability on plasmids in Rhizobium leguminosarum and Rhizobium phaseoli. Mol. Gen. Genet., 182: $133 \sim 136$

Hynes M F, N F McGregor . 1990. Two plasmids other than the nodulation plasmid are necessary for formation of nitrogen-fixing nodules by Rhizobium Leguminosarum. Mol. Microbiol., 4: 567 574

Hynes M F, R Simon. P Muller, et al., 1986. The two megaplasmids of Rhizobium meliloti are involved in the effective nodulation of alfalfa. Mol. Gen. Genet., 202: 356 362

Keyser H H, B B Bohlool, T S Hu, et al., 1982. Fast-growing rhizobia isolated from root nodules of soybean. Science, 215: $1631 \sim 1632$

Krol A J M. J G J Hontelez, A van Kammen. 1982. Only one of the large plasmids in Rhizobium leguminosarum strain PRE is strongly expressed in the endosymbiotic state. J. Gen. Microbiol., 128: $1839 \sim 1847$

Mirza N A, B B Bohlool, P Somasegaran , 1990. Non-destructive chlorophyll assay for screening of strains of Bradyrhizobium iaponicum. Soil Biol. Biochem., 22: 203 207

Ronson C W, D B Scott. 1983. Identification, broad host range mobilization and mutagenesis of a Rhizobium trifolii Sym: : R68. 45 cointergrate plasmid. In:Puhler A ed., Moleculor Genetics of Bacteria-plant Interaction, Berlin and Heidelberg: Springer, 177 187

Rosenberg C. P Boistard. J Denarie, et al., 1981. Genes controlling early and late functions in symbioses are located on a megaplasmid in Rhizobium meliloti. Mol. Gen. Genet. , 184: 326 333

Thurman N P, D M Lewis, D G Jones, 1985. The relationship of plasmid number to growth, acid tolerance and symbiotic efficiency in isolates of Rhizobium trifolii. J. Appl. Bacteriol., 58:1 6

Young J P W. W Wexler, 1988. Sym plasmid and chromosomal genotypes are correlated in field populations of Rhizobium leguminosarum.J. Gen., Microbiol., 134: 2731 2739

Zurkowski W, 1982. Molecular mechanism for loss of nodulation properties of Rhizobium trifolii. J. Bacteriol., 150: 999 1007 
Chen Wenli et al. : Variation of Sym Plasmid and Symbiotic Effectiveness in Isolates of Rhizobium fredii

(a)

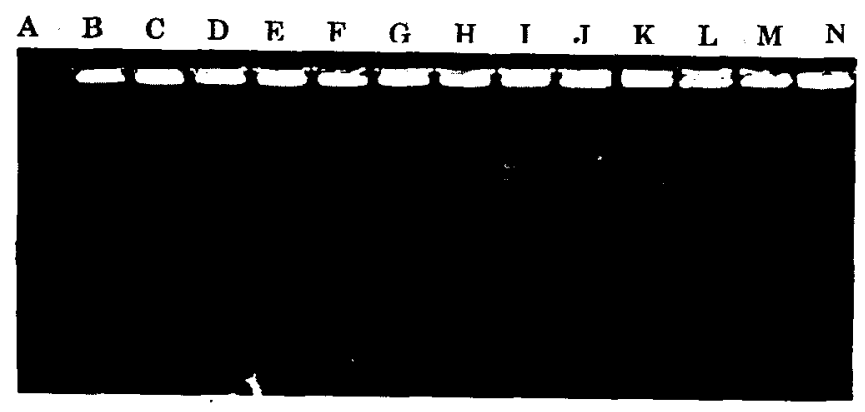

(b)

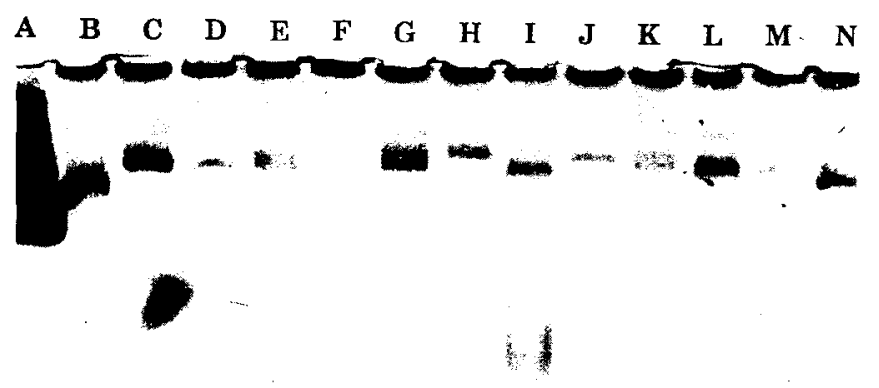

(a)

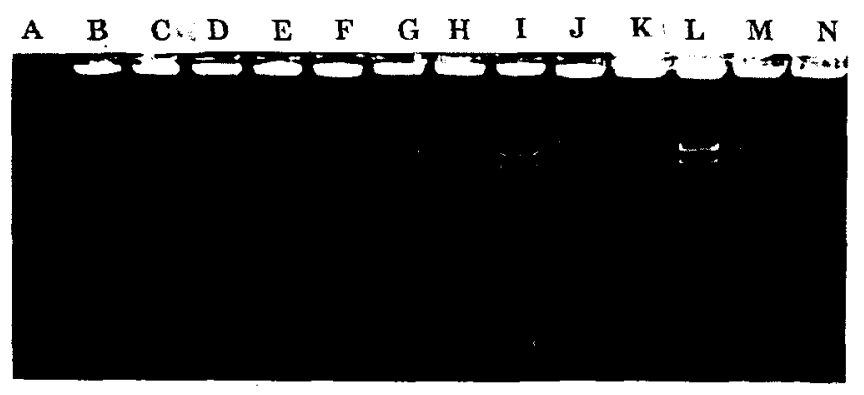

(b)

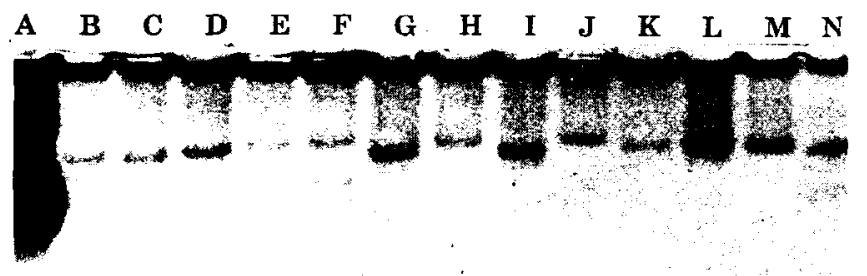

tic Effectiveness in Isolates of Rhizobi-
Fig. 1 Plasmid profiles and location of nif' genes
in R. fredii strains
a. Plasmid electrophoretic pattern an a
0.65\% agarose gel
b. Hybridization with nif HDK probe
A. pSA30 DNA; B. N. reference strain
R. fredii USDA205; C. HA9-1-10; D.
HA6-1-20; E. HA13-2-1; F. HA7-2-2;
G. HA8-1-8; H. HA13-2-6; I. HA9-1-
9; J. HA8-1-4; K. HA12-1-11; L.
HA12-1-12; M. HA1-1-4
Fig. 2 Plasmid profiles and location of nod
genes in R. fredii strains
:

tiveness in Isolates of Rhizobi-
Plasmid profiles and location of nif'genes
in $R$. fredii strains
a. Plasmid electrophoretic pattern an a
0.65\% agarose gel
b. Hybridization with nif HDK probe
A. pSA30 DNA; B. N. reference strain
R. fredii USDA205; C. HA9-1-10; D.
HA6-1-20; E. HA13-2-1; F. HA7-2-2;
G. HA8-1-8; H. HA13-2-6; I. HA9-1-
9; J. HA8-1-4; K. HA12-1-11; L.
HA12-1-12; M. HA1-1-4
Plasmid profiles and location of nod
genes in R. fredii strains
:

a. Plasmid electrophoretic pattern on a

$0.65 \%$ agarose gel

b. Hybridization with nodDABC probe A. p广J1216; B. N. reference strain $R$. fredii USDA205; C. HA9-1-10; D. HA6-1-20; E. HA13-2-1; F. HA7-22 ; G. HA8-1-8; H. HA13-2-6; I. HA9-1-9; J. HA8-1-4; K. HA12-111; L. HA12-1-12; M. HA1-1-4

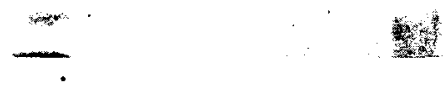

